\title{
The Future Role of Renewable Energy Sources for the Generation of Electricity in the European Region
}

\author{
Jorge Morales Pedraza*
}

\author{
Independent Consultant on International Affairs, Austria
}

\begin{abstract}
The development and use of renewable energy sources for electricity generation, particularly energy from wind, hydro, solar, biomass and geothermal, is a central aim of the European Commission's Energy Policy. For this reason, it is important to know what could be the role that renewable could play within the EU energy mix during the coming years, based on the role that this type of energy sources is now playing. The use of renewable energy sources for the generation of electricity is expected to be economically competitive in comparison with the use of conventional energy sources with the same purpose, will reduce the negative impact on the environment and the population as a result of the burn of fossil fuels, and will reduce the cost of the energy bill in the medium to long-term.
\end{abstract}

Keywords: Renewable, hydrology, solar, wind, geothermal power.

\section{INTRODUCTION}

The increase use of renewable energy sources for electricity generation is a central aim of the European Commission's Energy Policy reflected in the Directive 2001/77/EC (2001) $)^{1}$. The reasons for adopting this policy are:

a) The use of renewable energy sources for electricity generation has an important role to play in reducing $\mathrm{CO}_{2}$ emissions;

b) Increasing the share of renewable energy sources in the European energy balance enhances sustainability;

c) Helps to improve the security of energy supply by reducing the growing dependence of the region on imported fossil fuels (Morales Pedraza, 2008).

Renewable energy sources are expected to be economically competitive with conventional energy sources for electricity generation in the medium to longterm, despite the fact that most of the European countries are deeply dependent on the use of fossil fuels for the generation of electricity, and have in place all the necessary facilities to use this type of energy sources in the most economical manner.

*Correspondence to this Author: E-mail: jmorales47@hotmail.com, jmorales547@yahoo.com

\footnotetext{
${ }^{1}$ The Directive 2001/77/EC defines the energy from renewable sources as "energy from non-fossil fuel sources that is wind, solar, aero-thermal, geothermal, hydrothermal, ocean energy, hydropower, biomass, landfill gas, sewage treatment gas, and biogases.
}

While solar and wind power is growing at 20 percent and 30 percent, respectively, and their costs are decreasing rapidly, their market share is minuscule compared to the scale of oil and natural gas market.

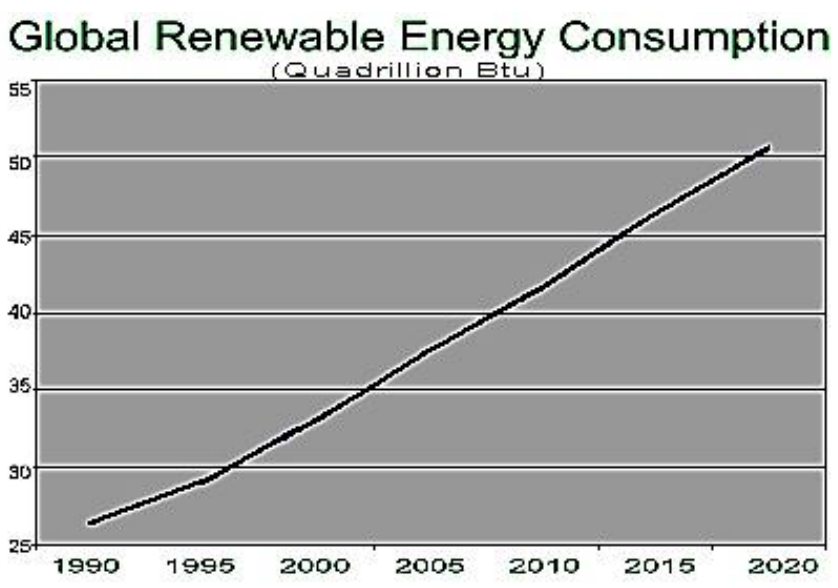

Figure 1: Global renewable energy consumption.

Source: US Department of Energy.

According to Figure 1, the consumption of different types of renewable energy sources is expected to increase from around 26 quadrillion BTU in 1990 to a little bit over 50 quadrillion of BTU in 2020. The increase use of this type of energy source during the period 2025-2020 and beyond, will has a positive impact on the environment and the population as well as in several economic sectors.

The European Union (EU) has ambitious targets in the field of environment. According to the EEA Technical Report No 6/2009, the new climate-energy legislative package sets mandatory national target corresponding to a 20 percent share of renewable energies in overall community energy consumption by 2020, and a mandatory 10 percent minimum target to 
be achieved by all EU Member States for the share of renewable energy in transport consumption by 2020 .

The 2009 EC Directive on the promotion of the use of renewable energy sources (2009/28/EC) not only set mandatory renewable energy targets for each EU Member State, but drafted a trajectory on how to reach these targets. The EC Directive also improves the legal framework for promoting the use of renewable for the generation of electricity, requires national action plans that establish pathways for the development of renewable energy sources, creates cooperation mechanisms to help achieve the targets cost effectively, and establishes the sustainability criteria for the use of biofuels as an energy source for the generation of electricity.

According to Figure 2, Sweden is the country within the European region with the highest percentage in the use of renewable energy sources for the generation of electricity in 2005, and the country with the highest possibility to reach the target established by the EU in 2020, followed by Latvia, Finland, Austria and Portugal.

In the EU, the satisfaction of energy needs is crucially linked to the security of energy supply and to the commitments to reduce greenhouse gas emissions.
The development of distributed generation and renewable electricity generation technologies are essential to achieve these goals and to reduce the cost of the energy bill in all EU Member States. In the longterm, Europe has a vision of a sustainable energy system where hydrogen and electricity act as the two main energy forms with fuel-cell technology providing the bridge between them. Together, these interchangeable energy carriers provide a unique pathway to gradually decreasing Europe's dependence on fossil fuels, and reducing greenhouse gas emissions and pollutants.

\section{EU RENEWABLE ENERGY POLICY}

Ambitious targets are at the core of the EU's policies to promote the generation of electricity from renewable energy sources. The EU sets out a strategy for the increase in the use of renewable for electricity generation in the document called "Energy for the Future: Renewable Sources of Energy White Paper for a Community Strategy and Action Plan 1997". The document mentioned early set the goal of doubling the share of renewable energy in the EU's energy mix during the coming years. The EC Directive 2001/77 is the most important piece of legislation ever introduced for the promotion of the use of renewable energy

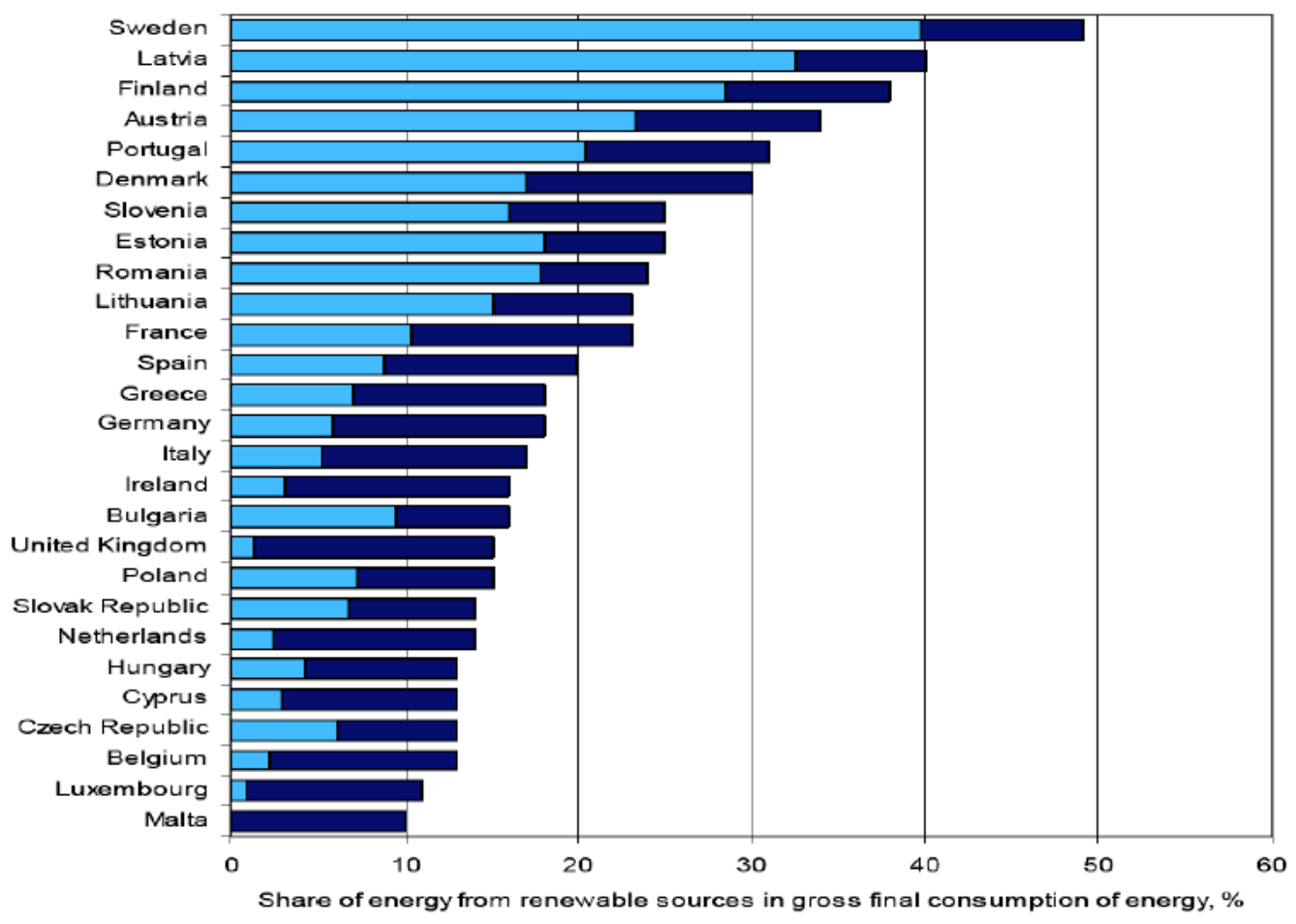

口RES \% 2005 a RES \% target 2020

Figure 2: Share of energy from renewable energy sources in 2005 and targets for the year 2020.

Source: Ruska and Kiviluoma (2011). 


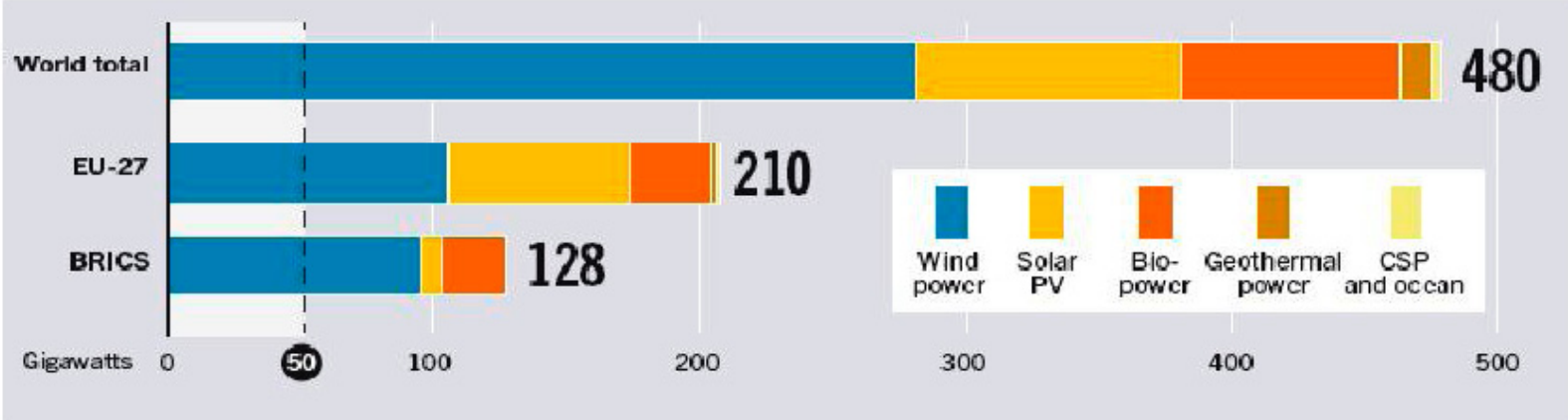

Figure 3: Renewable power capacities in the world, EU-27, BRICS, and top six countries, 2012.

Source: REN 21 (2013).

sources for electricity generation within the EU, and has led the EU-28 Member States to develop frameworks for investment in renewable, including financial instruments and ways of overcoming administrative barriers and grid access barriers. The EC Directive 2001/77 sets national indicative targets for the production of electricity from renewable energy sources as a percentage of gross electricity consumption.

The main elements of the EU renewable energy policy are the following:

a) Introduction of internal market measures;

b) Reinforcement of those EU energy policies, which allows an increase penetration of the renewable energies in the energy balance of the EU Member States;

c) Strengthening the co-operation between EU Member States in the use of renewable energy sources for electricity generation.

d) Support measures to facilitate investment and enhance dissemination and information in the renewable energy fields.

\section{SHARE OF RENEWABLE ENERGY SOURCES IN GROSS DOMESTIC ENERGY CONSUMPTION}

For 2020, it is expected that the share of renewable energies in gross domestic energy consumption in the EU reach 20 percent, and a binding 10 percent target for the share of renewable energy in transport petrol and diesel, instead of a target of 5.5 percent previously approved. This implies that the EU power sector continues its move away from the use of fuel oil, coal and, in some countries, nuclear power for electricity generation, whilst at the same time increasing its total installed capacity to meet growing power demand. The net growth in the last eleven years of natural gas power (118.2 GW), wind power (74.3 GW) and solar photovoltaic $^{2}(26.4 \mathrm{GW})$ was at the expense of fuel oil (down $13.2 \mathrm{GW}$ ), coal (down 9.5 GW) and nuclear energy (down 7.6 GW). The decrease in the role of nuclear energy in the energy mix of the EU will be even higher in the coming years due to the closure of nuclear power plants in Germany, France, Sweden, Switzerland, Belgium, and the UK, among others.

The total renewable capacities installed in the EU27 in 2012 were reported at $210 \mathrm{GW}$, which represents 43.75 percent of the total. The majority of the renewable capacities installed are wind power, followed by solar photovoltaic and geothermal power.

The data and analysis included in the renewable energy progress report \{SWD (2013) 102 final\} prepared by the EC in 2013 shows that while the EU as a whole is on its trajectory towards the 2020 targets, some EU Member States need to undertake additional efforts to fulfil their commitments. Whilst EU Member States have had seven years to achieve the first 20 percent of their target for 2012, thereafter they have only two years to achieve the next 10 percent for 2014 , 15 percent for 2016, 20 percent for 2018, and 35 percent in 2020. In addition, the significant change in economic circumstances in Europe and the negative

\footnotetext{
${ }^{2}$ There are two types of solar renewable technologies. The first is solar photovoltaic. This type of solar power is at best marginally efficient when converting energy from sunlight into electricity. And when the sun is not shining...well you get it. The second, solar thermal involves putting mirrors on motors to track sunlight. The mirrors concentrate the light to generate heat, which then boils water to drive turbines. This technology can store the excess heat in molten salt. But it is expensive when compared to the first technology. But, what if both technologies are combined in order to create a hybrid system? Then the conversion inefficiencies of the former would be offset by the continuous energy that could be gained from the latter. Overall the amount of energy from sunlight could top 50 percent conversion efficiency. A combination of solar photovoltaic panels with solar thermal would give the best of both technologies. This is something that will increase the efficiency in the use of solar power for electricity generation in the future.
} 
impact of the economic and financial crisis affecting the whole EU since 2008 will result, according to an analysis undertaken for the EC, in current policies being insufficient to trigger the required renewable energy deployment in a majority of the EU Member States.

\section{NEW RENEWABLE ELECTRICITY CAPACITY INSTALLED}

Since 1995, a systematic increase in the installation of new renewable capacity in the $E U$ has been reported. In 1995, the new installed renewable capacity was almost irrelevant in comparison to other energy sources, but after 2005 the new installed renewable capacity increases more than three folds. Renewable energy is OECD Europe's fastest-growing source of electricity generation, and it is expected to increase by 2.5 percent per year through 2035. In the EU, renewables accounted for almost 70 percent of the additions to electric capacity in 2012, mostly from solar photovoltaic and wind power. In 2011 (the latest year for which data are available), renewable met 20.6 percent of the region's electricity consumption and 13.4 percent of gross final energy consumption (REN 21, 2013).

In the case of wind power it has grown rapidly during the past 12 years. Installed capacity has increased more than 7.6 folds from around $13 \mathrm{GW}$ in 2000 to more than $100 \mathrm{GW}$ in 2012 (Fitch-Roy et al., 2013). Due to the increase in wind new capacities, during this period at present wind power dominates the non-hydro new capacity mix with a total participation of 28.8 percent. During the period 2010-2030 it is expected an increase in wind onshore of 207 percent and in wind offshore of 51.7 folds.

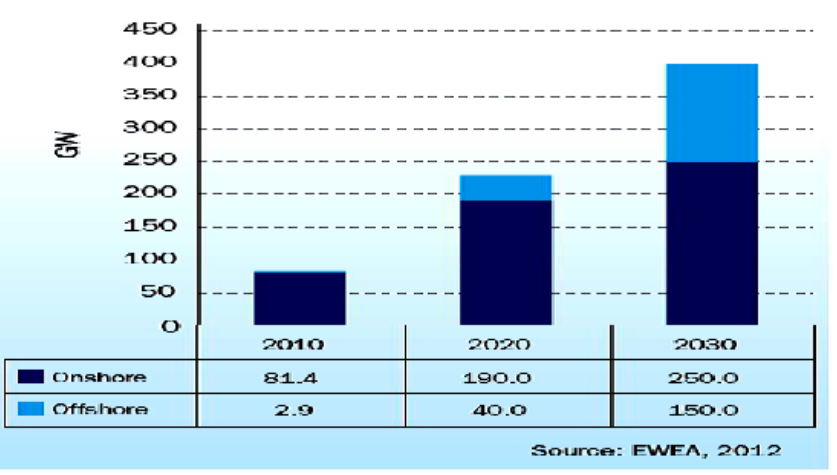

Figure 4: Wind energy capacity projection.

Source: EWEA 2012.

According to Global Market Outlook for Photovoltaics until 2015 Report, over the past decade, the solar photovoltaic market has experienced unprecedented growth. In particular in the last year, the solar photovoltaic market has reached a cumulative installed capacity of roughly $40 \mathrm{GW}$ world-wide, with an annual added capacity of $16.6 \mathrm{GW}$ in 2010. In 2012, the solar photovoltaic capacity reached $102 \mathrm{GW}$ worldwide. This capacity is capable of producing as much annual electrical energy as 16 coal power plants or nuclear reactors of $1 \mathrm{GW}$ each. Each year these solar photovoltaic installations save more than 53 million tons of $\mathrm{CO}_{2}$ (Masson et al., 2012).

The solar photovoltaic power is well on the way to becoming a fully competitive part of the electricity system in the EU and an increasingly important part of the energy mix around the Globe. But much of the progress in recent years has been very heterogeneous, varying from country to country, due to several factors, the most important being different national regulations and incentive schemes as well as the varying availability of financing facilities.

In Europe, the region accounted for around 22.7 GW of new installed solar photovoltaic capacity in $2011^{3}$. In 2012, the new total installed solar photovoltaic capacity reported was around $16.6 \mathrm{GW}$ and was considered enough to produce roughly 2.6 percent of the region's electricity demand, and about 5.2 of peak electricity demand, according to the European Photovoltaic Industry Association (EPIA). In 2013, over 37 GW worth of solar photovoltaic capacity was installed worldwide. It is important to highlight that in 2012, Europe's solar new photovoltaic installations fell from 22.7 GW in 2011 to $16.6 \mathrm{GW}$ in 2012, its first decline since 2006 .

Summing up can be stated that over the past ten years, the solar photovoltaic industry grew in Europe until reached an accumulative capacity of $69 \mathrm{GW}$ and the production costs have decreased by around 60 percent. In 2011, Europe accounted for 74 percent of the world's new solar photovoltaic installations; in 2012 this number was around 55 percent; this represents a reduction of $19 \%$. In 2013, it is almost certain that the majority of new solar photovoltaic capacity in the world will be installed outside of Europe, due to the natural cooling down period after very strong growth in the previous two years (Masson et al., 2012). Germany,

\footnotetext{
${ }^{3}$ The yearly electricity produced by solar photovoltaic could power a country with the electricity demand of Austria, which corresponds to 2 percent of the EU's electricity needs.
} 


\begin{tabular}{|c|c|c|c|c|}
\hline & $\begin{array}{c}\text { Installed } \\
2011\end{array}$ & $\begin{array}{l}\text { End } \\
20111\end{array}$ & $\begin{array}{c}\text { Instaled } \\
2012\end{array}$ & $\begin{array}{l}\text { End } \\
2012\end{array}$ \\
\hline \multicolumn{5}{|c|}{ EU Capacity (MW) } \\
\hline Austrla & 73 & 1084 & 296 & 1,378 \\
\hline Belgium & 191 & 1.078 & 297 & 1,375 \\
\hline Bulgarla & 28 & 516 & 168 & 684 \\
\hline Cyprus & 52 & 134 & 13 & 147 \\
\hline Czech Republle & 2 & 217 & 44 & 200 \\
\hline Denmark & 211 & 3,956 & 217 & 4,162 \\
\hline Estoria & 35 & 184 & 86 & 269 \\
\hline Fniand & 2 & 199 & a9 & 208 \\
\hline France & 830 & 6,807 & 757 & 7,564 \\
\hline Germany & 2,1 & 29,071 & 2,415 & 31,305 \\
\hline Greece & 316 & 1.634 & 117 & 1,749 \\
\hline Hungary & 34 & 329 & 0 & 329 \\
\hline Ireland & 208 & 1,614 & 125 & 1,738 \\
\hline Italy & 1,09 & 6,878 & 1,273 & 8,144 \\
\hline Latva & 17 & 48 & 21 & 68 \\
\hline Lthuanla* & 16 & 179 & 46 & 225 \\
\hline Luxembourg" & 1 & 45 & 0 & 45 \\
\hline Malta & 0 & 0 & 0 & 0 \\
\hline Nethertands & 59 & 2,272 & 119 & 2,391 \\
\hline Pctand & 436 & 1,616 & 680 & 2,497 \\
\hline Portugal & 341 & 4,379 & 145 & 4,525 \\
\hline Fomanla & 520 & 982 & 923 & 1,905 \\
\hline Słovakla & 0 & 3 & 0 & 3 \\
\hline Sovenla & o & 0 & 0 & o \\
\hline Spain & 1,05 & 21,674 & 1,122 & 22,796 \\
\hline Sweden & 754 & 2,899 & 846 & 3,745 \\
\hline Unked Kungdom & 1,298 & 6,556 & 1,897 & 8,445 \\
\hline Total EU-27 & 9.664 & 94,352 & 11,895 & 108,040 \\
\hline Total audis & 8.6024 & 00,145 & 0.714 & $99,6 E_{2}$ \\
\hline Total EU-12 & 1140 & 4,207 & 2,181 & 6,388 \\
\hline
\end{tabular}

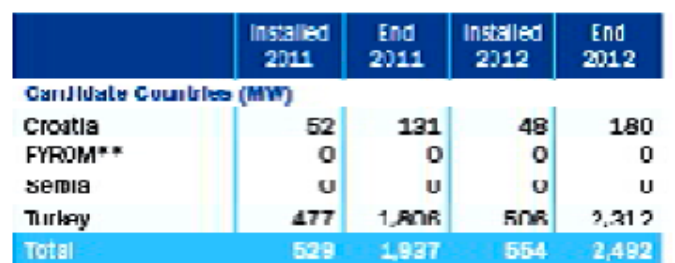

Total

EFTh (MW)

iralsna

Llechitenstel n

Norway

Ewhaorland

Total

Othu (MW)

Uhralne

Rusaga

Totsl

Thtal Furnep

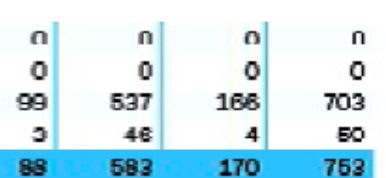

Note: dus to prevous year scjustrments, 207 MW of project

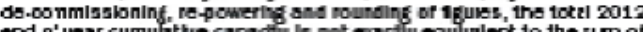

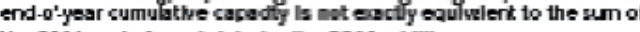

the zo11 end-oryear tots pus the 2012 soumions.

Figure 5: Wind power installed in Europe by the end of 2012.

*Provisional.

${ }^{* *}$ Former Yugoslav Republic of Macedonia.

Source: EWEA report 20112.

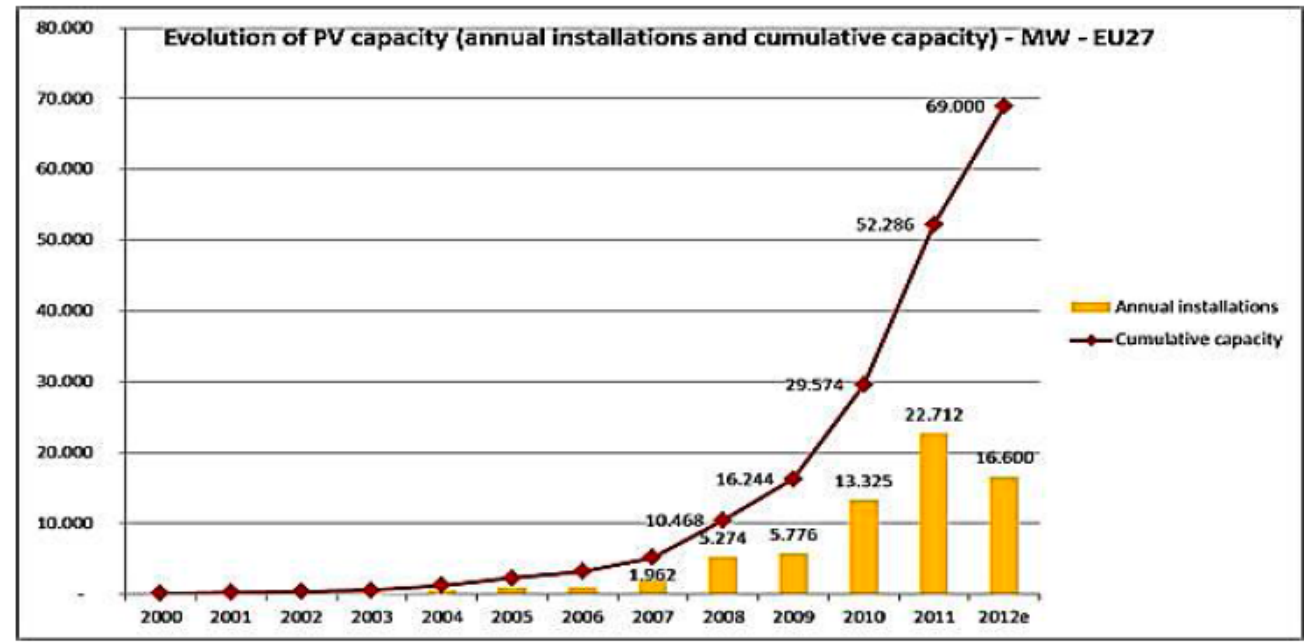

Figure 6: Evolution of solar photovoltaic during the period 2000-2012.

Source: EPIA.

Italy, Spain, the Czech Republic, France, Belgium, and the United Kingdom are the leaders in installed solar photovoltaic capacity in Europe.

In 2012, at least 78 countries used geothermal energy directly for the generation of electricity. Over two-thirds of the geothermal energy for direct use was through geothermal heat pumps. Twenty-four countries operated geothermal plants for electricity production. Total geothermal electricity capacity was $11.7 \mathrm{GW}$ at the end of 2012. Capacity was led by the U.S. with 3.4 $\mathrm{GW}$ of capacity, followed by the Philippines at $1.9 \mathrm{GW}$, Indonesia at $1.3 \mathrm{GW}$, Mexico at $1 \mathrm{GW}$, and Italy at 0.9 GW. On a per capita basis, Iceland leads the world with 


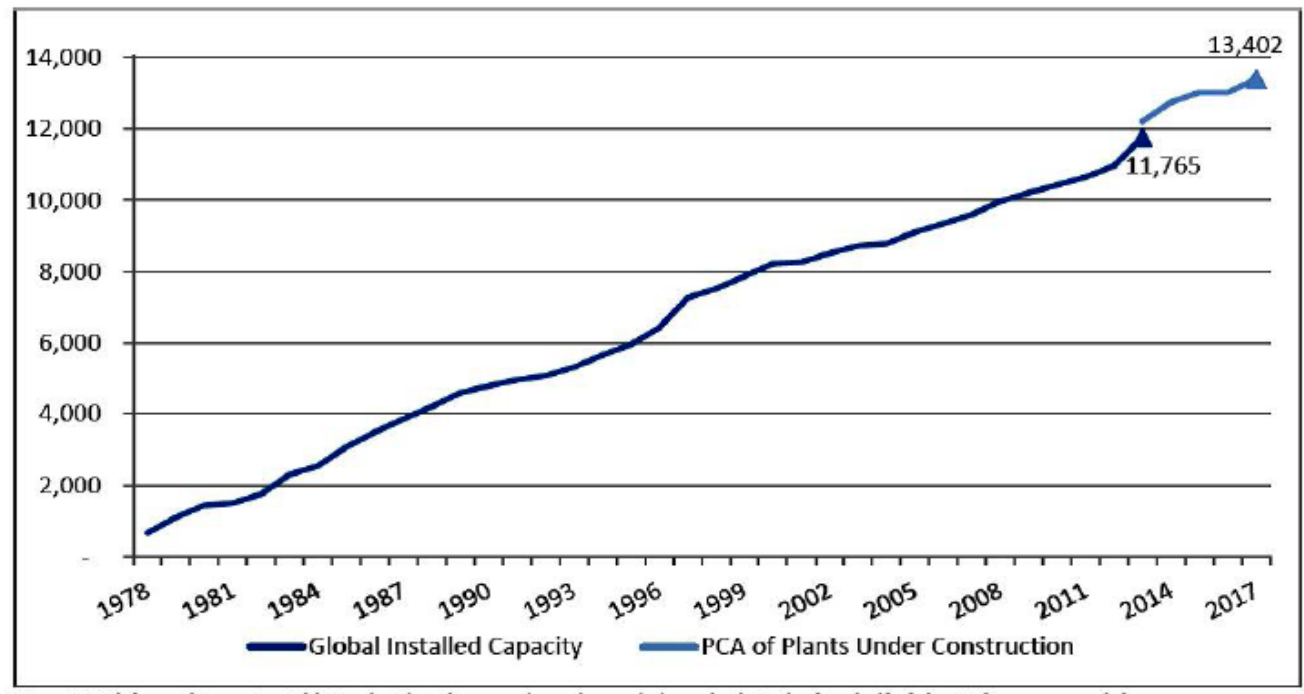

Note: PCA (Planned Capacity Additions), Pilot plants and geothermal plants built in the first half of the 20th century and then

decommissioned are not included. Source: Author

Figure 7: Global installed geothermal capacity and power plants under construction.

Source: Mattek (2013).

$0.7 \mathrm{GW}$ of capacity, which accounted for 30 percent of the country's electricity in 2012. Europe has a substantial amount of geothermal projects under development and 15 projects actually under construction. With the exception of Iceland and Italy, these projects are traditionally smaller projects of less than $10 \mathrm{MW}$ (Mattek, 2013). It is expected that in 2017, the total geothermal power capacity could reach 13.4 GW if all power plants under construction can be finished as planned.

\section{ELECTRICITY GENERATION}

The need for an EU support for the use of renewable energy source for electricity generation is clear. According to EWEA (2011), the increase in electricity generated from renewable energy sources is a result of the fact that a majority of newly installed generating capacity is renewable ${ }^{4}$. It is important to highlight that not only some of the new technologies, especially wind energy, small-scale hydropower and solar thermal applications, are economically viable and competitive with respect other energy sources, but European reserves of some of the fossil fuels are limited and the main reserves of these types of energy sources are located outside of the EU, in some cases in instable political areas.

\footnotetext{
${ }^{4}$ Generating electricity from renewable energy sources has a high priority in the energy policy strategies at national and European level as well as at a global scale. Challenging goals for this new kind of electricity generation have been set, e.g. at European level by the Directive on the Promotion of Electricity from Renewable Energy Source (European Parliament and Council, 2001) as well as the "White Paper on Renewable Sources of Energy" (COM 1997).
}

The use of renewable energy sources for electricity generation, such as geothermal, upgrading of largescale hydropower plant or co-firing of biomass is characterized by from an economic point-of-view comparatively low cost and by, in contrast, rather limited future potentials in most countries. Wind energy and in some countries also small-scale hydropower or biomass combustion (in large-scale power plant) represent renewable energy sources for electricity generation with economic attractiveness accompanied by a high additional realizable potential. A broad set of other renewable energy sources for electricity generation technologies are less competitive at present, compare e.g., agricultural biogas and biomass - both if utilized in small-scale power plants, solar photovoltaic, solar thermal electricity, tidal energy or wave power - although, future potentials are in most cases huge (Resch et al., 2006).

The EU target is truly ambitious and will require major efforts by all EU Member States. The contribution of each EU Member State to achieve the EU's target will need to take into account different national circumstances and starting points, including the nature of their energy mix. EU Member States should have the flexibility to promote the renewable energies most suited to their specific potential and priorities. In practice, in implementing their plans EU Member States will need to set their specific objectives for electricity, biofuels, heating and cooling, which would be verified by the EC to ensure that the overall target is being met (COM, 2007). 
According to the IEO (2010 and 2013) reports, renewable energy is the fastest-growing source of electricity generation within the different energy sources available in the world that can be used for this specific purpose. The use of renewable energy sources for electricity generation is expected that almost triples during the period 2010-2035. Total generation from renewable resources is expected to increase by 2.5 percent annually, and the renewable share of world electricity generation is expected to grow from 21 percent in 2010 to 25 percent in 2040.

In the case of the EU, the EC Directive 2001/77 approved in 1977, included as it main aim an increase the renewable energy's share of electricity generation from 14 percent in 1997 to 21 percent in 2010 in the EU-25; this means an increase of 7 percent. Only few countries achieved this objective.

Six EU Member States increased their shares by more than 2 percent during 2000s, thereby contributing significantly to the development of the renewable energy's total share of electricity generation in the EU. Such growth has occurred primarily via expansion of the use of solid biomass and wind energy.

According to the IEO (2013), almost 80 percent of the projected increase in renewable electricity generation is fueled by hydropower and wind power ${ }^{5}$. Of the 5.4 trillion $\mathrm{kWh}$ of new renewable generation that will be added until 2040, a total of 2.8 trillion kWh (52 percent) is attributed to hydroelectric power and 1.5 trillion $\mathrm{kWh}$ (28 percent) to wind. Most of the growth in hydroelectric generation (82 percent) will occur in the non-OECD countries, and more than half of the growth in wind generation (52 percent) will occur in the OECD countries, mostly in the European region. Undoubtedly, hydropower remains the single biggest renewable energy source for the generation of electricity, though its overall share falls slightly, from 16 percent to 15.5 percent in the past years.

\footnotetext{
${ }^{5}$ The mix of the two renewable energy sources differs dramatically between the OECD and non-OECD regions. In OECD nations, most economically exploitable hydroelectric resources already have been developed. Except in a few cases-notably, Canada and Turkey-there are few opportunities to expand large-scale hydroelectric power projects, particularly in the EU. Instead, most renewable energy growth in OECD countries is expected to come from non-hydroelectric sources, especially wind. Many OECD countries, particularly those in Europe, have government policies (including feed-in tariffs, tax incentives, and market share quotas) that encourage the construction of wind and other non-hydroelectric renewable electricity facilities. More than 70 percent of the projected growth in OECD renewable energy sources is attributed to non-hydroelectric renewables (IEO, 2013).
}

In the case of wind power, this type of energy source is growing most in terms of generation. The participation of wind energy for the generation of electricity has grown swiftly over the past decade a trend that continues into the future (World Wind Energy Report 2009, 2010). In the EU, the contribution of wind power was more than doubles in the past years reaching 43 percent of the total (WEO, 2012).

The European Wind Energy Association's has set a target of $230 \mathrm{GW}$ of new wind capacity by 2020 , including $40 \mathrm{GW}$ of offshore wind, which would meet 20 percent of the region's electricity demand. If current growth rates continue, all renewables could meet between 35 and 40 percent of total consumption in Europe by 2020, generating around 1400 TWh.

High construction costs can make the total cost of building and operating renewable generators higher than those for conventional plants. The intermittence of wind and solar energy, in particular, can further hinder the economic competitiveness of those resources, as they are not necessarily available when they would be of greatest value to the system. However, improving battery storage technology and dispersing wind and solar generating facilities over wide geographic areas, could help to mitigate some of the problems associated with the use of these two types of energy sources over the projection period.

Continued growth of the renewable sector within the EU will require major access to the grid and additional public resources. With that in mind, EU Member States were required to adopt and submit National Renewable Energy Plans, within which each State has to set out how the country expects to reach its legally binding 2020 renewables target, the technology mix it expects to use, and the measures and reforms it expects to undertake to overcome development and deployment barriers.

According to the National Renewable Energy Action Plans (NREAPs) approved, the EU-27 will exceed its target of meeting 20 percent of its gross final energy consumption from renewable energy sources by 2020 . This means that 34.6 percent of the EU's total electricity consumption should come in 2020 from renewable energy sources. The contribution of each renewable energy source will be the following:

- $\quad$ Wind energy - 14 percent (494.7 TWh from 213 GW installed capacity); 
Table 1: Renewable Electricity Generation by Energy Source During the Period 2007-2035

\begin{tabular}{|c|c|c|c|c|c|c|c|}
\hline Sources & $\mathbf{2 0 0 7}$ & $\mathbf{2 0 1 5}$ & $\mathbf{2 0 2 0}$ & $\mathbf{2 0 2 5}$ & $\mathbf{2 0 3 0}$ & $\mathbf{2 0 3 5}$ & $\begin{array}{c}\text { Average annual } \\
\text { percent change } \\
\text { 2007-2035 }\end{array}$ \\
\hline \hline Hydro power & 2999 & 3689 & 4166 & 4591 & 5034 & 5418 & 2.1 \\
\hline Wind & 165 & 682 & 902 & 1115 & 1234 & 1355 & 7.8 \\
\hline Geothermal & 57 & 98 & 108 & 119 & 142 & 160 & 3.7 \\
\hline Solar & 6 & 95 & 126 & 140 & 153 & 165 & 12.7 \\
\hline Others & 235 & 394 & 515 & 653 & 773 & 874 & 4.8 \\
\hline Total & 3462 & 4958 & 5817 & 6618 & 7336 & 7972 & 3 \\
\hline
\end{tabular}

Source: IEO 2010.

- $\quad$ Hydro - 10.5 percent (370.3 TWh from $136 \mathrm{GW}$ of installed capacity $)^{6}$;

- $\quad$ Biomass - 6.7 percent (232 TWh from $43 \mathrm{GW}$ of installed capacity);

- $\quad$ Solar PV - 2.4 percent (83.3 TWh from $84 \mathrm{GW}$ of installed capacity);

- $\quad$ Concentrated solar power - 0.5 percent (20 TWh from $7 \mathrm{GW}$ of installed capacity);

- $\quad$ Geothermal - 0.3 percent (10.7 TWh from 1.6 $\mathrm{GW})$;

- $\quad$ Tidal, wave and ocean - 0.2 percent (5.8 TWh from $2 \mathrm{GW}$ of installed capacity).

Taken together the NREAPs it can be expected that the EU-27 has the possibility to meet 20.7 percent of its 2020 energy consumption of different renewable energy sources. Fifteen EU Member States plan to exceed their national target, led by Bulgaria at +2.8 percent above its target, Spain ( +2.7 percent), Greece (+2.2 percent), Hungary (+1.7 percent) and Germany (+1.6 percent). Ten EU Member States will meet their national target, and just two EU Member States, Luxembourg (-2.1 percent) and Italy (-0.9 percent), have informed the EC that they envisage using the cooperation mechanisms to meet their national targets.

According to Ruska and Kiviluoma (2011), in 2020, the total renewable energy electricity production in the EU is estimated to be $1217 \mathrm{TWh}$ based on NREAPs

\footnotetext{
${ }^{6}$ Hydropower represents the dominating renewable energy source for electricity generation technology, holding a share of 89 percent in 2002. However, over the last decade a huge growth in the use of other renewable energy source for electricity generation options occurred, in particular, bioenergy (including biomass and waste incineration) and wind power increased their share, especially in Europe (Resch et al., 2006).
}

approved. If the NREAPs are fully implemented, Austria, Sweden, and Latvia will have the largest renewable energy electricity production shares in 2020. For the whole EU, wind power's share of the total consumption is projected to be 14 percent and solar power share almost 3 percent. Variable generation shares vary considerably between countries and electricity market areas. Ireland has the largest projected wind power share of 37 percent, followed by Denmark (31 percent), Greece (25 percent), and Spain (21 percent). Large solar power shares are projected in Spain (8 percent), Germany (7 percent), and Greece (5 percent).

In June 2010, the EC's Joint Research Centre highlighted that if the current growth rates of the renewable electricity generation sources can be maintained in the coming years, up to 1600 TWh (4550 percent) of renewable electricity could be generated in 2020."

From Table 1, the following can be stated: In absolute terms hydropower will be the renewable energy sources with the highest participation in the EU energy mix in 2035 with 67.9 percent, followed by wind with 16.9 percent. Solar and geothermal are the renewables with the lower participation in the EU energy mix in 2035 with 2 percent each. However, solar power is the type of renewable energy source with the highest average annual percentage increase during the period 2007-2035 (12.7 percent) followed by wind power ( 7.8 percent).

\section{ECONOMIC IMPLICATIONS OF THE EU ENERGY TARGETS}

To achieve a 20 percent share for renewable energies within the EU energy mix, it will result in an additional average annual cost of approximately $€ 18$ 


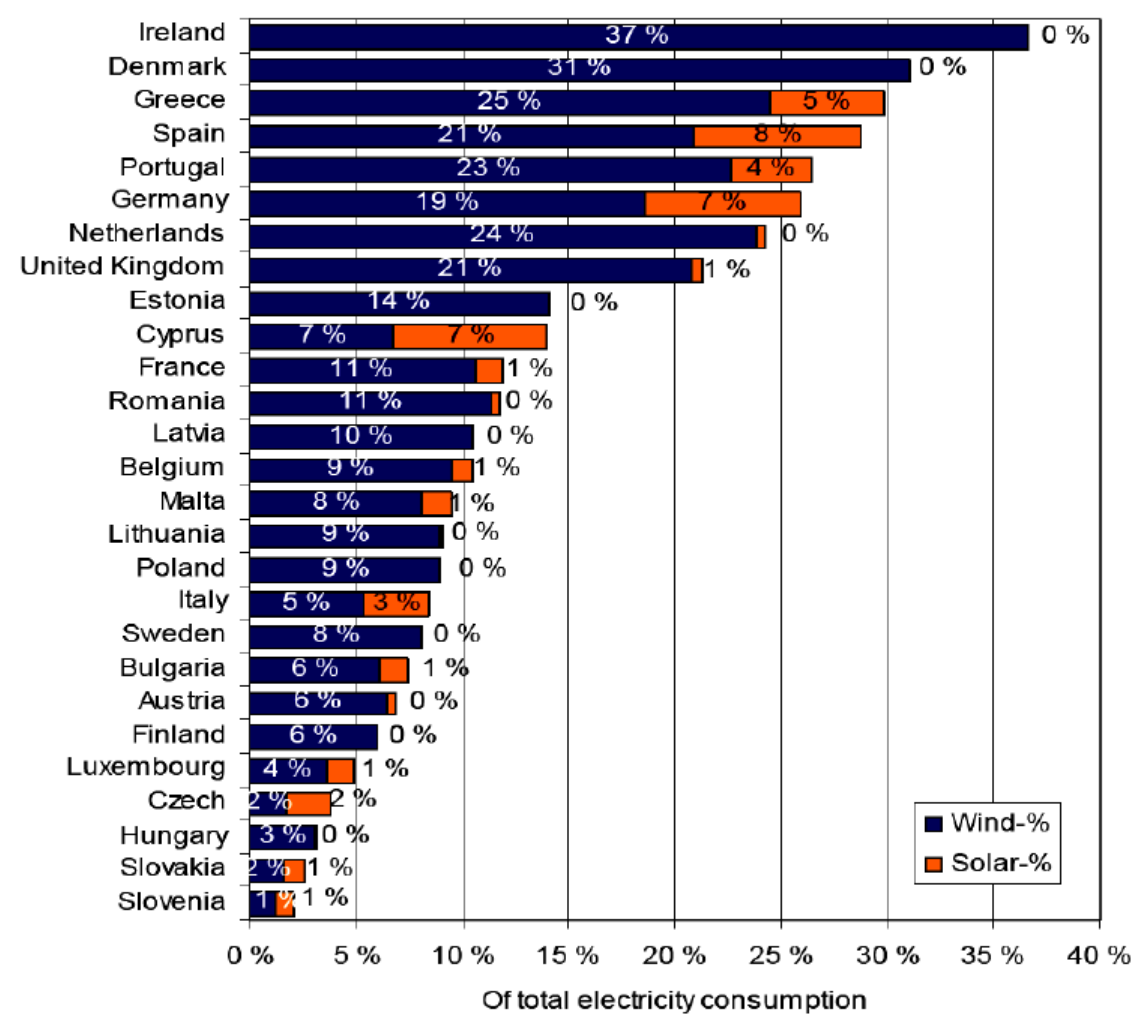

Figure 8: Projected winds and solar power shares of the total projected gross final electricity consumption in 2020. Source: Ruska and Kiviluoma (2011).

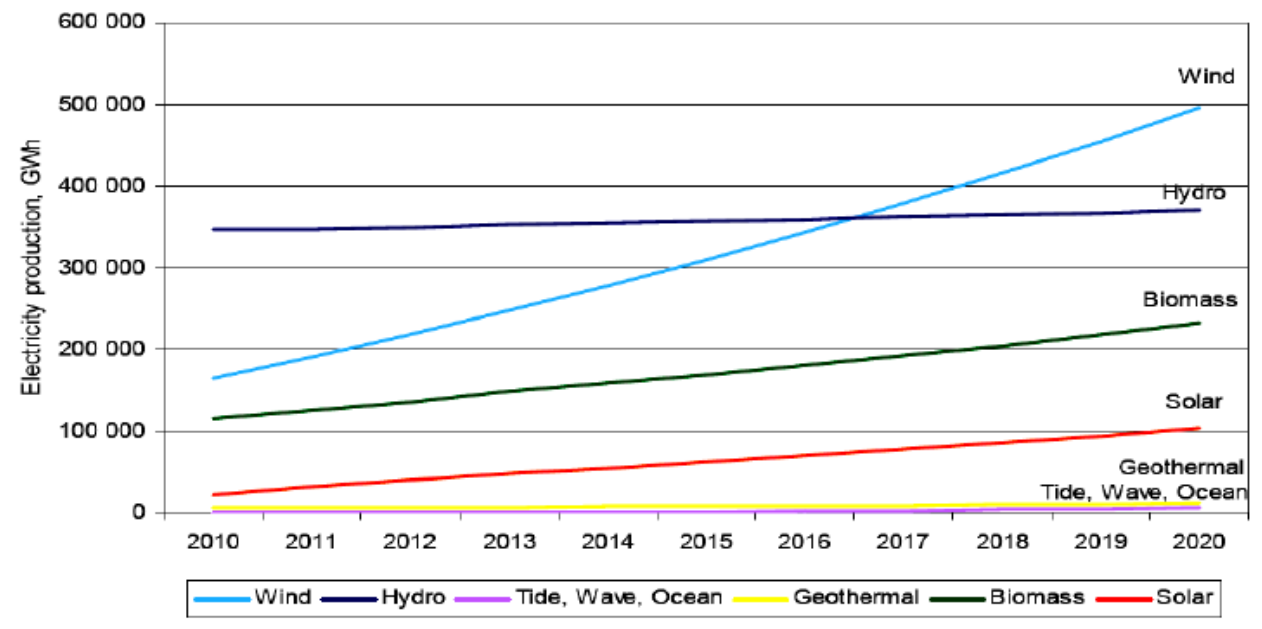

Figure 9: Individual renewable energy source technologies' projected trajectory for EU-27.

Source: Ruska and Kiviluoma (2011).

billion - around 6 percent extra on the EU's total expected energy import bill in $2020^{7}$. However, it is

${ }^{7}$ Investment in renewable energy reached new heights in 2011 (US\$ 257 billion) a rise of 17 percent on the previous year. The record investment was a six-fold increase on the 2004 figure and nearly double the total in 2007, the year before the world financial crisis begin, according to a report from the United Nations Environment Programme (UNEP) entitled Global Trends in Renewable Energy Investment 2013 and to the document entitled REN21 Renewables 2013 Global Status Report. important to highlight that this calculation has been made assuming an oil price of US $\$ 48$ per barrel by 2020. If this price rose to US $\$ 78$ per barrel, the average annual cost would fall to US $\$ 10.6$ billion, an important reduction of US\$7.4 billion. But with an oil price of around US\$130 per barrel, which is a realistic price for oil for that year, the average annual cost will fall further. If a carbon price of more than $€ 20$ were factored in, the 20 percent would cost practically no 
more than relying on conventional energy sources, but create many jobs in Europe, develop new technology driven European companies, and reduce the negative environmental impact of the use of fossil fuels for the generation of electricity.

The EC estimates that "additional investments between $€ 10$ and $€ 15$ billion are required to achieve the energy target the EU has set itself." The main factors that should be taken into account are the following:

- Using renewable energy sources today for electricity generation is generally more expensive than using hydrocarbons, but the gap is narrowing - particularly when the costs of climate change are factored in;

- Economies of scale can reduce the costs in the use of renewable energy source, but this needs major investment today;

- The use of different renewable energy sources for electricity generation helps to improve the EU's security of energy supply by increasing the share of domestically produced energy, diversifying the fuel mix and the sources of energy imports and increasing the proportion of energy from politically stable regions as well as creating new jobs in Europe;

- The use of renewable energy sources for electricity generation emits few or almost no greenhouse gases, and most of them bring significant air quality benefits.

Although renewable energy sources have positive environmental and energy security attributes, most renewable technologies today other than hydroelectricity are not able to compete economically with fossil fuels outside of a few regions. Solar power, for instance, is currently a "niche" source of renewable energy, but can be economical where electricity prices are especially high, where peak load pricing occurs, or where government incentives are available.

Wind and solar are intermittent technologies that can be used only when resources are available. Once built, the cost of operating wind or solar technologies when the resource is available is generally much less than the cost of operating other renewable and conventional energy sources for electricity generation. However, high construction costs can make the total cost to build and operate renewable energy power plants higher than those for conventional power plants. The intermittence of wind and solar can further hinder the economic competitiveness of those resources, as they are not operator-controlled and are not necessarily available when they would be of greatest value to the system. The use of energy storage (such as hydroelectric pumped storage, compressed air storage, and batteries) and a wide geographic dispersal of wind and solar generating facilities could mitigate many of the problems associated with these types of energy sources in the future.

\section{THE COST OF ELECTRICITY}

The cost of electricity depends on the supply and demand sizes: The supply-side is determined by the unit costs of electricity and the resulting potentials. In a liberalized and competitive market these costs have a major influence on the energy sources chosen for electricity generation.

As long as an overcapacity of power plants exists to meet electricity demand, no new power plant is necessary to meet the demand. The EU considered that the difference between the maximum level of electricity generation and the peak in the demand of electricity should be no less than 5 percent.

With future demand growth and plant replacement, new capacity has to be constructed. Competition between different new generators is influenced by the total costs of electricity generation. In both cases, costs depend on the applied conversion technology and the applied energy source, respectively. The escalating prices of crude oil and natural gas as supply dwindles has prompted some reluctant governments to further consider investment in renewables. However, conventional types of renewable energy resources with widespread practical usage all require initial capital investments that often dwarf what is required for natural gas and coal power plants. Fortunately, the increase in research and development has yielded cheaper production methods and more durable, costeffective materials that continue to bring these costs down.

In an effort to assess the real viability of alternative energy solutions on a large-scale, it is useful to compare the cost per kilowatt-hour ( $\mathrm{kWh}$ ) for each of the most common types of renewable energy resources. The cost in cents per $\mathrm{kWh}$ includes initial capital costs (amortized), maintenance, fuel and waste disposal costs, when applicable. Tax incentives are built into the calculations. 
- Wind: US\$0.09-US\$0.22/kWh. The use of lightweight, but durable materials and more aerodynamic designs have significantly lowered the production cost of the wind turbine. Cost alone is not the only concern when considering wide-scale deployment of wind farms. Susceptibility to failure from mechanical fatigue, the inability to function well in the rain or in cold climates, and the noise created from vibration, should all be taken into account when considering the true cost of using this type of energy source. Despite the substantial upfront investment required for the generator, it requires a marginal operating cost of less than US\$0.01 per kWh.

- Geothermal: US\$0.09/kWh. The considerable variability of costs for this renewable energy resource comes largely from the type of plant constructed and the depth of drilling required. Boasting incredible uptime of more than 97 percent, geothermal plants can operate more efficiently and consistently than coal plants with uptimes of around 70 percent. Binary geothermal plants (currently the preferred technology) are small, and can be built in a variety of different places including acreages and rural farmland. Even though they are smaller, they still carry a higher initial investment than natural gas plants. Despite the sustainability of its free fuel source, the high cost of well drilling and pipeline construction prevent many of these plants from ever being built.

Hydro: US\$0.09/kWh. Hydropower is the most practical and universal of renewable energy resources. While they can only be built in a limited number of places due to the extraordinary amount of space required, hydropower plants are the most efficient source of green electricity and contribute no waste or emissions into the environment. Environmentalists argue that large hydroelectric power projects destroy marine ecosystems and disrupt fragile habitats. In response to these protests, governments and private enterprise have developed several cutting-edge technologies such as hydrokinetic power systems that generate power without the need for dams.

- Solar: US $\$ 0.14$ (Photovoltaic); US $\$ 0.26 / \mathrm{kWh}$ Thermal). Solar power systems include photovoltaic and solar-thermal. The high cost of these types of renewable energy sources is largely due to the high price of silicon crystals. Silicon prices continue to rise as their widespread production applications are leading to supply shortages. However, newly developed alternative materials could bring the cost down below US $\$ 0.05 / \mathrm{kWh}$ in the near future (Annual Energy Outlook, 2013).

The environmental benefits of using electricity generated by renewable energy sources unarguably outweigh any financial drawbacks. Nonetheless, it is still prudent to consider the real financial viability of each of these leading types of renewable energy resources as a real alternative to fossil fuel-based energy.

By looking closer at a certain energy source, another important correlation appears; namely the correlation between costs of electricity generation and the availability of capacity. Because every energy source used for electricity generation has limitations, costs depend on previous exploitation and installed capacity. Hence, strategies for a forced market penetration of renewable energy sources for electricity generation in a future electricity market must be based on a detailed analysis of costs and potentials for electricity generation from different renewable energy sources.

On the other hand, demand for renewable energy sources for electricity generation is determined by a number of factors, including:

a) The industrial economic point-of-view. The price of conventional electricity is set by supply and demand of electricity in general. According to specific market conditions across Europe, this price differs by country and by sub-region. These differences will continue to change due to the ongoing liberalization process. Under the assumption that no other promotional instrument exists, the price of conventional electricity would determine the market penetration of renewable energy sources for electricity generation. In this case, only the quantity of green electricity would be produced that could be generated to lower or equal costs than the according conventional price level;

b) Willingness to pay for electricity generated from renewable energy sources. Voluntary approaches to promote renewable energy 
sources for electricity generation (e.g., green tariffs) are based on consumers' willingness to pay voluntarily more for green electricity. It is important to highlight that can in Denmark, Luxembourg, Netherlands, Finland and Sweden, the percentage of people who voluntarily sought green electricity is larger than in other countries, and so their demand for renewable energy sources for electricity generation is large compared with other countries. Nevertheless, there usually exist important divergences between real demand and the aspiration shown in surveys. There is an important interaction between regulatory and voluntary approaches, with huge impact on the latter one (Menges, 2003). This interaction relates to the existing asymmetrical relationship between both approaches, which explains the relatively poor readiness of German consumers, facing a high regulatory demand for renewable energy sources for electricity generation, to pay more for green electricity, despite their well-known environmental awareness;

c) Promotion instruments for renewable energy sources for electricity generation on the demand-side. To promote renewable energy sources for electricity generation, a mandatory demand could be set by the government. Assuming, a quota for renewable energy sources for electricity generation is introduced, a mandatory (inelastic) demand for electricity from renewable energy sources results (Resch et al., 2006).

\section{CONCLUSION}

It is important to highlight that within the EU renewable energy sources all of them are indigenous, they do not rely on the future availability of conventional sources of energy, and their predominantly decentralized nature makes EU countries' economies less vulnerable to volatile energy supply. Consequently, they constitute a key element of a sustainable energy future. However, for renewables to become the "stepping stone" to reaching the dual objective of increased security of supply, reduce the cost of the energy bill, and reduce greenhouse gas emissions, a change in the way in which the EU promotes renewables is needed. Strengthening and expansion of the current EU regulatory framework is also necessary. It is important also to ensure that all EU Member States take the necessary measures to increase the share of renewables in their energy mix (COM (2008)).

With the exception of existing hydroelectric facilities, almost all of the power generation capacity required to supply Europe in 2050 will need to be built in the next three or four decades. This is a major undertaking regardless of the energy mix, and would pose a massive challenge even in a high-carbon scenario. The cost implication of such tasks is enormous and a billion of euros in new investment in the EU energy sector will be needed.

Based on the elements included in the previous sections of this paper, the following can be stated:

1. The renewable electricity sector within the European region is a quite advanced sector with already well developed market and business structures. Most of the activities reach beyond general awareness raising and promotion. Issues like favorable, reliable and forwardlooking policy frameworks, investment security, access to electricity grids and fair regulation, operation and maintenance dominate the picture;

2. Although the sector is generally very dynamic and well developed, it still faces considerable regulatory, administrative, and grid barriers in order to increase the role to be played by renewables in the EU energy mix during the coming decades;

3. The dissemination efforts in promoting the use of renewable energy sources for electricity generation in the European region have generally improved considerably, but still need to be given even higher priority. Not all EU Member States have adopted the necessary measures in order to increase the role of renewable in their energy mix. In times of a growing flood of information, information needs to be well targeted, concise, and well prepared in order to reach the respective target groups;

4. Electricity customers (residential customers and also business firms) are interested in green power products and look for independent ecolabels as guidance to their purchase decision. However, the cost of the introduction and expansion of renewables are not cheap and additional measures should be adopted in order to reduce the energy bill; 
5. The regulatory framework should include incentives for distribution system operators to integrate distributed generation. The remuneration schemes for operational and capital expenditures and the benchmarking procedures should take into account the connection and management of distributed generation. Additional incentives should be considered to promote innovation and research and development activities by distribution system operators;

6. Deep connection charges that include reinforcement costs should be avoided. Either a shallow charging policy could be adopted or the use of system pricing methodology could be reformulated to allow the financial recognition of distributed generation contribution to the network costs:

7. Participation of distributed generation in ancillary service and balancing markets can be enhanced, if market rules accept aggregation of small individual generators. The timeframe for announcing estimated production in balancing arrangements should become smaller;

8. EU Member States apply very different, inconsistent and non-transparent procedures and rules for interconnection and connection charging of new distributed generation and renewable energy sources market entrants. This creates unnecessary risk and uncertainty to project developers, and it leads to market distortion. As a result of the above, there is an urgent need for novel, consistent and panEuropean approaches to distributed generation, interconnection rules and connection charging across the whole of the EU;

9. Current national systems for tracking electricity are mainly focused on national markets, vary considerably among countries and their design and interaction with related policies lead to significant volumes of multiple counting and loss of information;

10. The design of a tracking standard for electricity is a delicate issue for market participants and should be developed carefully in order to produce useful results, for example for electricity disclosure, but at the same time not to create negative impacts on the liquidity of electricity markets. The preferred tracking system should feature an efficient mechanism for explicit tracking, preferably based on certificates, combined with an option to use a residual mix, which consists of statistical generation data, which is corrected by those attributes that have been tracked explicitly;

11. Wind power, solar photovoltaic and geothermal sectors is expected to achieve the European targets set in the EC White Paper. Other sectors need more incentive from the individual EU Member States in order to achieve these targets;

12. In different EU Member States there still exist a variety of different, non-transparent cost allocation and cost reimbursement principles for grid integration of renewable electricity and system operation. It is important to harmonized these principles in order to expand the energy market;

13. From the grid-operators' points-of-view, at present there exist no incentives for large-scale grid integration of renewable electricity, since the corresponding grid-related costs are hardly eligible in the grid regulation/grid tariff determination procedures;

14. Comprehensive quantitative analysis (renewable electricity modelling, and empirical renewable electricity case studies) provide evidence that the "overall costs" of large-scale intermittent grid integration of renewable electricity (including system operation costs and grid reinforcement/extension costs) are still below 10 percent of the long run marginal costs of the renewable electricity generation technology itself;

15. Solar photovoltaic policy measures and starting positions vary strongly from country to country. Therefore, close cooperation, deepened crossnational discussions and actions are absolutely necessary, also after finishing the project. Especially the National Position Papers and Action Plans will help the respective countries for an improved political discussion of solar photovoltaic. Although the core group of the Solar Photovoltaic Policy Group already gathered eight nations, it is desirable that the results are disseminated and used in nonparticipating EU countries (European 
Commission's Intelligent Energy Executive Agency, 2006).

\section{REFERENCES}

An energy policy for Europe (2007); Communication from the Commission to the European Council and the European Parliament, Brussels, Belgium, 10.1.2007 COM(2007) 1 final, SEC(2007); 2007.

Annual Energy Outlook 2013 with Projections to 2040 (2013); DOE/EIA-0383 (2013); USA; 2013.

COM (2008) 782, Brussels 13.11.2008 SEC (2008) 2869; 2008.

Directive 2001/77/EC (2001); Promotion of electricity produced from renewable energy sources in the internal electricity market; European Commission; Brussels, Belgium; September 2001.

Directive 2009/28/EC of the European Parliament and of the Council of 23 April 2009 on the promotion of the use of energy from renewable sources and amending and subsequently repealing Directives 2001/77/EC and 2003/30/EC; 2009.

EEA Technical report No 6/2009; Europe's onshore and offshore wind energy potential An assessment of environmental and economic constraints (2009); European Environment Agency, ISSN 1725-2237; 2009.

Electricity from Renewable Energy Sources: 13 Innovative Projects supported by the IEE Programme (2006); European Commission's Intelligent Energy Executive Agency; http://ec.europa.eu/energy/intelligent/library/publications_en. htm; 2006.

EWEA (2011); Towards more sustainable events; MCI Sustainability and the European Wind Energy Association; 2011.

Energy for the future: Renewable sources of energy (1997); European Commission (COM (1997); Communication from the Commission, White Paper for a Community Strategy and Action Plan; 1997.

Fitch-Roy, Oscar; Albero, Carlo; Barber, Sarah; Hill, Beckie; Gadner, Paul; Phillips, Joseph; Gagliardi, Filippo; Hjuler, Peter (2013); Workers wanted: The EU wind energy sector skills gap (2013); European Wind Energy Technology Platform; 2013.

Global Market Outlook for Photovoltaics until 2015 (2011); European Photovoltaic Industry Association (EPIA); Brussels; Belgium; 2011.

International Energy Outlook 2010; Energy Information Administration (EIA), Department of Energy; DOE/EIA-0484 (2010); USA; 2010.
International Energy Outlook 2011; Energy Information Administration (EIA), Department of Energy; DOE/EIA-0484 (2010); USA; 2011.

International Energy Outlook 2013; Energy Information Administration (EIA), Department of Energy; DOE/EIA-0484 (2013); USA; 2013.

Masson, Gaëtan; Latour, Marie; Rekinger, Manoël; Theologitis, loannis-Thomas; and Papouts, Myrto (2012); Global Market Outlook for Photovoltaics 2013-2017; European Photovoltaic Industry Association (EPIA); Brussels, Belgium; 2012.

Mattek, Benjamin (2013); 2013 Geothermal Power: International Market Overview; Geothermal Energy Association; Washington, USA; September 2013.

Morales Pedraza, J. (2008); The Current Situation and the Perspectives of the Energy Sector in the European Region; Chapter 1 of the book titled Energy in Europe: Economics, Policy and Strategy; Nova Science Publisher; New York, USA; 2008.

On the promotion of use of energy from renewable sources; proposal for a Directive for the EU Parliament and the Council, Brussels 23.01.2008 COM (2008); 2008.

REN21 (2013); Renewables 2013 Global Status Report; Paris: REN21 Secretariat; ISBN 978-3-9815934-0-2; Paris, France; 2013.

Report from the Commission to the European Parliament, the Council, the European Economic and Social Committee and the Committee of the Regions; Renewable energy progress report \{SWD (2013) 102 final\}; Brussels, 27.3.2013 COM (2013) 175 final; Brussels, Belgium; 2013.

Resch, Gustav; Faber, Thomas; Haas, Reinhard; Ragwitz, Mario; Held Fraunhofer, Anne; and Konstantinaviciute, Inga (2006); Potentials and cost for renewable electricity in Europe (2006); Report (D4) of the IEE project OPTRES: Assessment and optimisation of renewable support schemes in the European electricity market; Vienna University of Technology, Institute of Power Systems and Energy Economics, Energy Economics Group; Vienna, Austria; February 2006.

Ruska, Maija and Kiviluoma, Juha (2011); Renewable electricity in Europe. Current state, drivers, and scenarios for 2020 (2011); VTT Technical Research Centre of Finland; 2011.

World Wind Energy Report 2009 (2010); World Wind Energy Association WWEA; Germany; 2010.

World Energy Outlook 2012; International Energy Agency, ISBN: 978-92-64-18084-0; France; 2012.

(c) 2014 Jorge Morales Pedraza; Licensee Lifescience Global.

This is an open access article licensed under the terms of the Creative Commons Attribution Non-Commercial License (http://creativecommons.org/licenses/by-nc/3.0/) which permits unrestricted, non-commercial use, distribution and reproduction in any medium, provided the work is properly cited. 